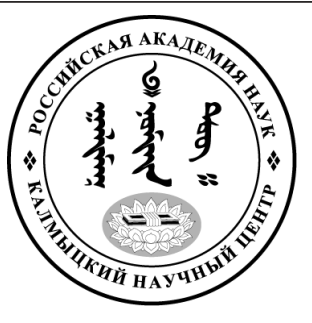

Published in the Russian Federation

Oriental Studies (Previous Name: Bulletin of the Kalmyk Institute

for Humanities of the Russian Academy of Sciences)

Has been issued as a journal since 2008

ISSN: 2619-0990; E-ISSN: 2619-1008

Is. 5, pp. $855-871,2019$

DOI: $10.22162 / 2619-0990-2019-45-5-855-871$

Journal homepage: https://kigiran.elpub.ru

УДК 903.02(470.6)»653»

\title{
Импортная поливная керамика Маджара как источник по изучению международной торговли в Золотой Орде
}

\author{
Петр Михайлович Кольцов ${ }^{1}$ Бауыржан Абишевич Байтанаев², \\ Юрий Дмитриевич Обухов
}

${ }^{1}$ Калмыцкий государственный университет им. Б. Б. Городовикова (д. 11, ул. Пушкина, 358000 Элиста, Российская Федерация)

доктор исторических наук, профессор, заведующий кафедрой всеобщей истории ORCID: 0000-0001-9776-3650. E-mail: petrkoltsov52@mail.ru

${ }^{2}$ РГКП «Институт археологии им. А. Х. Маргулана» Комитета науки МОН Республики Казахстан (д. 28, ул. Шевченко, просп. Достык 44, 050010 Алматы, Республика Казахстан) доктор исторических наук, академик Национальной академии наук Республики Казахстан ORCID: 0000-0002-2013-0473. E-mail: baytanaev@mail.ru

\footnotetext{
${ }^{3}$ Калмыцкий государственный университет им. Б. Б. Городовикова (д. 11, ул. Пушкина, 358000 Элиста, Российская Федерация) аспирант кафедры всеобщей истории ORCID: 0000-0003-2008-788X. E-mail: obuxova_t@inbox.ru
}

Аннотация. Введение. В статье рассматривается импортная глазурованная (поливная) керамика, обнаруженная на городище Маджар во время сборов и археологических раскопок разных лет. Первая классификация поливной керамики Маджара была проведена О. А. Дудко в 70-е гг. XX в. по материалам раскопок В. А. Городцова в 1907 г. и сборов Северо-Кавказской экспедиции в 1955 г. В результате данной работы исследовательница выявила как местную, так и импортную поливную посуду из Средней Азии, Закавказья и Поволжья. В конце XX и начале XXI в. количество находок импортной поливной керамики из Маджара значительно увеличилось, поэтому авторы данной статьи вновь обратились к описанию, анализу и систематизации одного из самых массовых археологических материалов. Источники и методы. Источниковой базой послужила импортная поливная керамика, собранная на Маджаре в течение ряда лет. Основными критериями для систематизации керамических комплексов были выбраны следующие методы: визуально-описательный, статистический, типологический, технологический, сравнительного анализа и аналогий. Результаты. В ходе исследования были выявлены широкие торговые связи средневекового Маджара, которые наглядно отражают находки импортной поливной керамики. Среди них выделяются следующие группы: кашинная керамика Поволжья, Ирана, Средней Азии (Хорезм); красноглиняная поливная керамика Нижнего Поволжья, Азака, городов восточной части Крыма, возможно, из Причерноморья, Средиземноморья и с Балкан; Ширванская группа керамики, Китайская керамика цычжоу, китайский селадон, китайский бело-синий фарфор (цинхуа), византийская керамика. Bыводы. На основе изучения морфологических и технологических особенностей импортной глазурованной (поливной) ке- 
рамики Маджара были выделены следующие ее категории: красноглиняная поливная керамика, селадон, кашинная керамика, керамика цычжоу, цинхуа, ширванская керамика, византийская керамика. Установлена датировка импортной поливной керамики Маджара в пределах XIV в. Соотношение групп импортной керамики указывает на более интенсивные торговые связи Маджара с Китаем, столицами Золотой Орды и городами Восточного Крыма. Значительно слабее отмечены контакты с Азаком, Хорезмом, Ширваном, Персией, городами Средиземноморья и Балкан.

Ключевые слова: Маджар, импортная поливная керамика, международная торговля, селадон, кашинная керамика, керамика цычжоу, ширванская керамика, византийская керамика

Благодарность. Исследование выполнено при финансовой поддержке Калмыцкого государственного университета им. Б. Б. Городовикова в рамках научного проекта № 1090 «Северная ветвь Великого Шелкового пути на участках Нижнее Поволжье - Калмыцкая степь - Северный Кавказ: изучение караван-сараев как связующего звена между городскими центрами средневековья».

Для цитирования: Кольцов П. М., Байтанаев Б. А., Обухов Ю. Д. Импортная поливная керамика Маджара как источник по изучению международной торговли в Золотой Орде. Oriental Studies. 2019;(5): 855-871. DOI: 10.22162/2619-0990-2019-45-5-855-871.

UDC 903.02(470.6)"653"

\title{
Investigating International Trade in the Golden Horde: Imported Glazed Ceramics from Majar
}

\author{
Petr M. Koltsov ${ }^{1}$ Bauyrzhan A. Baitanaev², Yuri D. Obukhov ${ }^{3}$ \\ ${ }^{1}$ Gorodovikov Kalmyk State University (11, Pushkin St., Elista 358000, Russian Federation) \\ Dr. Sc. (History), Professor, Head of Department of General History \\ ORCID: 0000-0001-9776-3650. E-mail: petrkoltsov52@mail.ru
}

${ }^{2}$ Margulan Institute of Archaeology (44, Dostyk Ave., 28, Shevchenko St., Almaty 050010, Republic of Kazakhstan)

Dr. Sc. (History), Academician, National Academy of Sciences of the Republic of Kazakhstan

ORCID: 0000-0002-2013-0473. E-mail: baytanaev@mail.ru

${ }^{3}$ Gorodovikov Kalmyk State University (11, Pushkin St., Elista 358000, Russian Federation)

Postgraduate Student, Department of General History

ORCID: 0000-0003-2008-788X. E-mail: obuxova_t@inbox.ru

\begin{abstract}
Introduction. The article deals with imported glazed ceramics discovered in the town of Majar during archeological excavations of various years. The first classification of Majar-discovered glazed ceramics was made in the 1970s by O. Dudko who analyzed materials of V. Gorodtsov's excavations (1907) and those of the 1955 North-Caucasian Expedition. The researcher discovered both local glazed pottery and ones imported from Middle Asia, Transcaucasia and the Volga Region. The late $20^{\text {th }}$ and early $21^{\text {st }}$ centuries have witnessed a significant increase in numbers of imported glazed ceramics from Majar, so the paper seeks to re-address the issue since the newly collected extensive data require proper description, analysis and systematization. Sources and Methods. The study examines imported glazed ceramics collected in Majar during various years. It employs a number of methods, such as the visual-and-descriptive, statistic, typological, technological ones, those of comparative analysis and analogy. Results. The work reveals residents of Majar maintained wide trade relations vividly illustrated by findings of imported glazed ceramics that played somewhat major role there. The latter cluster into categories as follows: kashi pottery from the Volga Region, Iran, Middle Asia (Khwarazm), red-clay glazed ceramics from the Lower Volga Region, Azaq (Azov), Eastern Crimea, supposedly from the Black Sea Region, Mediterranean and Balkans; Shirvan ceramics, Cizhou ceramics (China), Chinese celadon, Chinese white-blue porcelain (Qinghua), Byzantine ceramics. Conclusions. The analysis of morphological and technological features of imported glazed ceramics of Madjar reveals the following groups: glazed red-clay, kashi, Cizhou, Qinghua, Shirvan,
\end{abstract}


and Byzantine ceramics. The bulk of the samples are dated to the $14^{\text {th }}$ century AD. Proportions between the groups indicate that Majar maintained most intensive trade relations with China, capital cities of the Golden Horde, and eastern Crimea. Contacts with Azaq, Khwarazm, Shirvan, Persia, Mediterranean cities and the Balkans were far weaker.

Keywords: Majar, imported glazed ceramics, international trade, celadon, kashi ceramics, Cizhou ceramics, Shirvan ceramics, Byzantine ceramics

Acknowledgements: The reported study was funded by Gorodovikov Kalmyk State University, project number 1069 'Northern Branch of the Great Silk Road Covering the Lower Volga Region Kalmyk Steppe — North Caucasus: Investigating Caravanserais as Connecting Links between Medieval City Centers'.

For citation: Koltsov P. M., Baitanaev B. A., Obukhov Yu. D. Investigating International Trade in the Golden Horde: Imported Glazed Ceramics from Majar. Oriental Studies. 2019;(5): 855-871. DOI: 10.22162/2619-0990-2019-45-5-855-871.

\section{Введение}

Глазурованная (поливная) керамика является выразительным явлением керамического производства золотоордынского города. Её массовое производство обусловило доступность этой керамики всем слоям золотоордынского обществах. Массовостью производимой керамики объясняется и разнообразие орнаментальных мотивов, украшавших производимую посуду.

Кроме «местной» поливной керамики, на рынках золотоордынских городов пересекались потоки поливной посуды из стран Дальнего Востока, Средней Азии, Ирана, Византии, Восточного Закавказья и др.

Импортная керамика Маджара представлена обычным для степных городов 3олотой Орды набором. Она рассматривалась исследователями как в целом, так и по отдельным группам и видам.

Первая классификация поливной керамики памятника выполнена О. А. Дудко по схеме, принятой тогда в Поволжской экспедиции [Дудко 1963: 108-118]. Эта студенческая работа касалась только поливной продукции из раскопок В. А. Городцова 1907 г. и сборов Северо-Кавказской экспедиции (1955 г.), хранящихся в Историческом музее. В результате своих исследований автор пришла к выводу, что большая часть керамики производилась на месте, а некоторое количество привезено из Средней Азии, Закавказья и Поволжья [Дудко 1963: 117]. Между тем за последние десятилетия количество керамики и, прежде всего, поливной импортной с территории средневекового городища Маджар значительно увеличилось.
Цель работы - описание и анализ одного из самых массовых материалов керамики, ее импортной поливной части, полученной во время проведения археологических работ и сборов на средневековом городище Маджар, а также попытка ее систематизации и определение приоритетного направления торговых связей.

Хронологические рамки рассматриваемого материала ограничиваются временем функционирования города Маджара, т. е. концом XIII-XIV вв. В конце XIV в. в результате междоусобных войн и разрушительных походов армии Тимура были нарушены торговые и караванные связи, что привело к затуханию жизни в Маджаре.

Материаль и методы исследования. В работе были использованы визуальноописательный, формально-классификационный и технологический методы исследования. Возможности изучения средневековой керамики как исторического источника значительно расширились за счет привлечения дополнительных данных: письменных, изобразительных, археологических.

\section{Результаты}

Кашинная керамика Поволжья, Ирана, Средней Азии - устойчивый импорт во всех золотоордынских городах. Ее классификация по техникам нанесения декора и мотивам росписи наиболее полно сделана на материалах столиц Золотой Орды [Булатов 1969: 4-7; Фёдоров-Давыдов 1994: 78-124]. Она же рассматривалась в работах Э. Р. Ртвеладзе и Н. С. Гражданкиной [Гражданкина, Ртвеладзе 1971: 127-139]. 
Фрагментарные материалы Маджара не позволяют аргументированно добавить к этому что-то принципиально новое. Однако необходимо отметить, что в Маджаре бирюзовые и синие глазури (прозрачные и глушеные), используемые при производстве кашинной керамики, применялись довольно широко. Более того, в округе Маджара имеются выходы на поверхность белого кварцевого песка, который мог использоваться как сырьё для производства кашинной керамики.

Однако на сегодняшний день достоверных следов производства кашинной керамики в Маджаре не обнаружено, отсутствуют также находки печного припаса, необходимого при производстве данного вида керамики. Сказанное выше позволяет говорить об импорте данной продукции из Поволжья, а также возможно из Хорезма, Ирана и других стран.

Самые многочисленные отделы кашинной керамики Маджара следующие: полихромная с подглазурной росписью без рельефа; полихромная с подглазурной росписью рельефом; с подглазурной черной росписью и прозрачной бирюзовой глазурью; с бирюзовой, синей и белой глазурью. Менее представительные отделы кашинной керамики: с синей подглазурной кобальтовой росписью, копирующей китайскую цинхуа, обычно называемая тимуридской (рис. 1); с белой или зеленоватой глухой поливой без рельефа и с рельефом, копирующей китайский селадон; с белой глухой поливой с люстровой росписью; с синей поливой с люстровой росписью ${ }^{1 ;}$ ладжвардина; минаи. Под минаи следует считать кашинную керамику с белой или бирюзовой глазурью и полихромной надглазурной росписью с позолотой, а аналогичная с глазурью, окра-

1 Люстр (франц. lustre 'глянец, блеск', от лат. lustro 'освещаю') - глазурь и пигмент для росписи керамических изделий на основе серы, олова, свинца, оксидов серебра и меди. В результате восстановительного муфельного (низкотемпературного) обжига люстр проявляется на поверхности предмета в виде металлического или перламутрового блеска и усиливает живописный эффект декора. Художественная керамика с росписью люстром впервые появилась в конце VIII - начале IX в. в Египте, Ираке, Иране и Сирии. Эта ближневосточная техника оказала большое влияние на развитие испано-мавританских фаянсов XIII-XV вв. и итальянской майолики XV-XVI вв. шенной кобальтом в тёмно-синий цвет, ладжвардина (рuс. 2), производство которой было освоено в Иране.

Красноглиняная поливная керамика Нижнего Поволжья представлена только фрагментами и одним неполным кувшинчиком, который можно отнести к родственной группе из Азака, и значительным числом фрагментов разнообразных чаш с желтой и зеленой глазурью без орнамента, с подглазурной росписью ангобом и сграффито. Фрагментами представлены не только устойчивые отделы, но и образцы с нестандартными сочетаниями признаков, произведенными в больших мастерских с разделением труда и принципиально разными технологиями. Таковой является красноглиняная посуда, расписанная ангобом и прозрачной бирюзовой глазурью, которая в обычном случае использовалась только для кашинной керамики. Также наблюдается смешение техник при обработке поверхности красноглиняной посуды с черной росписью под прозрачной бирюзовой глазурью; с копией росписи кашинной полихромной керамики без рельефа; с копией росписи простейшей «тимуридской» керамики и просто с бирюзовой глухой глазурью.

Импорт из Азака представлен поливными чашами второй группы, которые выделяются темной поверхностью неполивной придонной части и неравномерностью обжига, видимого в изломах. Это сочетание признаков не характерно для городов Нижнего Поволжья, что позволяет связывать их с Азаком [Волков 2016: 196].

Группа керамики из Юго-Восточного Крыма выделяется на Маджарском городище весьма условно [Волков 1992: 9-10, 21]. Дело в том, что керамику трех самых больших городов, расположенных в восточной части Крыма - Солхата, Каффы и Судака, объединяет общая технология производства. Сходной была керамика их ближайшей округи. Однако по составу формовочных масс и способам декора к группе близка продукция многих центров Причерноморья, Средиземноморья и Балкан. В частности, часть продукции этой группы по форме поддонов бывает очень похожа на изделия Кипра [Веневцева 1997: 137, рис. 5-6].

Определенное количество находок из подъемного материала Маджара - это фрагменты чаш, аптечных двуручных кув- 
шинов, штампованных кувшинов с зеленой глазурью. Часть из них можно отнести к испано-мавританской люстровой керамике, которая была широко распространена в Средиземноморье и Причерноморье, хотя ее количество в целом уменьшается по мере удаления от источника производства. Маджарские фрагменты люстровой керамики имеют преимущественно желтовато-зеленоватое люстровое покрытие и датируются XIV в.

Ширванская группа керамики (рис. 3) легко выделяется из всего комплекса керамики на городищах по форме, технологии, составу формовочной массы и стилю росписи. Обоснованию ширванского происхождения группы керамика из Маджар посвящена отдельная статья [Волков 2001: 45-50]. Это преимущественно чаши, сделанные по донно-емкостной программе конструирования полого тела, со следами вырезания ножом полости кольцевого поддона. Один фрагмент дна допускает использование донного начина или наклеивание плоскости поддона после формовки основной ёмкости, но обычные следы вырезания ножом на нём также присутствуют.

Продукция этой группы представлена только фрагментами, но не приходится сомневаться, что основу ассортимента составляют две разновидности формы чаш [Волков 2001, рис. 1, 3]. В большинстве случаев это низкие широкие чаши с широким горизонтально отогнутым венчиком [Волков 2001: рис. 1,1-5, 7-9]. В редких случаях встречаются сосуды с вертикальным венчиком с утолщением снаружи [Волков 2001: рис. 1,10].

Все изделия группы имеют декор в технике сграффито и могут быть монохромными зелеными или полихромными, в исключительных случаях - монохромными c бирюзовой или желтоватой глазурью. Для гравировки использовали только тонкие линии приблизительно одной ширины. В исключительных случаях использовалось выскабливание ангобного фона (резерв) в сочетании с обычной гравировкой линией одной толщины [Волков 2001: рис. 2, 2-4].

Основной кроющей поливой полихромных сосудов, является светло-жёлто-зелёная, она лежит на всей внутренней поверхности (и частично внешней), однако внешняя чаще покрыта зеленой поливой. Интенсивный жёлтый и зелёный цвета использовались для расцвечивания выграви- рованных деталей орнамента, причем чаще всего без точного соответствия с линиями (но отклонения от контуров обычно незначительны); марганцевый краситель - для нанесения самостоятельных деталей орнамента (без гравировки), это обычно кольца, спирали, побеги, пятна из 3 точек. На внешней поверхности этим красителем наносили простейшие штриховки (чаще всего - обращённые вниз наклонные «арки»), которые часто оставались не покрытыми поливой. К редким находкам относится фрагмент зеленого блюда этой группы с остатками двух строк персидских стихов.

Немногочисленны находки импортов из района Отрара или смежных областей Средней Азии (рис. 4). Их отличительными признаками являются желтый цвет (при большей плотности, чем в Маджаре), только вырезные поддоны, вытянутые трещинки на поверхности, образовавшиеся при обработке гончарным ножом, перпендикулярные направлению его движения, фаска на внешней стороне края поддона. Наиболее распространенная техника росписи - красной и темно-коричневой нерастекающейся краской под желтой глазурью интенсивного цвета. Происхождение группы определено на основании того, что на Селитренном городище ее больше, чем в Азаке, а на среднеазиатских и казахстанских памятниках золотоордынского времени встречено значительное количество целых форм.

Китайская керамика изычжсоу (рис. 5). Хотя название произошло от мастерских Цычжоу яо (г. Хиньдань, провинция Хэбэй) [Евтюхова 1965: 221], очагов производства было много, об этом говорят существенные вариации состава формовочной массы, отличия в форме поддонов, цвете и плавкости глазурей. Вся эта керамика - не литая, а вытянутая на гончарном круге. Основные встреченные отделы: с глазурью белого цвета (обычно - слоновой кости); с аналогичной основной кроющей глазурью и подглазурной росписью коричневым; целиком покрытая коричневой глазурью, когда это именно покрытие, а не роспись. В этом случае возможно использование гравировки по сырой глазури. На фрагментах различимы лишь отдельные элементы изображения: драконов, цветов, иероглифов.

Селадон (рис. б) - самая распространённая группа китайского импорта. Традици- 
онно связывается с продукцией мастерских Лунцюань яо (провинция Чжэцзян) [Полубояринова 2003: 155], для которых характерна серая основа. Хотя считается, что цвет изделий старались приблизить к нефриту, его вариации весьма велики, что свидетельствует о возможности производства во многих местах. Основной способ декора связан с отливкой изделий в рельефной форме. При этом широко распространена гравировка одно- или многозубым резцом. В отдельных случаях можно говорить о применении концевых штампов. Устоявшееся название «селадон» - плод творчества торговцев и антикваров. Оно подразумевает зеленоватый цвет.

В золотоордынских слоях также широко представлены изделия со светлой голубоватой или почти белой глазурью, на совершенно белой основе.

Китайский бело-синий фарфор (иинхуа) (рис. 7). Находки фарфора с подглазурной росписью кобальтом в золотоордынских городах относятся преимущественно ко второй половине XIV в. Само изобретение техники кобальтовой росписи связано с Халифатом и относится примерно к IX в., но широкое распространение она получила при династии Юань (1271-1368). Главным центром производства фарфора был поселок Цзиндэчжень (провинция Цзянси) [Жущиховская 2002: 90].

Между тем в Китае самые ранние находки фарфора с росписью кобальтом относятся ко времени династии Тан (618-907), причем с заимствованиями ближневосточных элементов в росписи.

Набор элементов орнамента в XIV в. очень устойчив. На внешней стороне лепестки лотоса с двойным контуром и стрельчатым окончанием, на поле лепестка - также устойчивое изображение. Пояса часто заполнены двумя вариантами лозы с лепестками. Более широкие пространства занимают изображения цветов, драконов, сетки из ромбов со штрихами с внутренней стороны.

Несколько фрагментов фарфоровых изделий заслуживают особых комментариев, поскольку такие находки единичны на всей территории Золотой Орды. Это стенки и венчик фарфоровых чаш с голубоватой глазурью и надглазурной росписью. Часть надглазурной росписи осыпалась, а остав- шаяся не позволяет даже сказать, каков был цвет эмали, из-за глубокой иризации.

Особого внимания заслуживает фрагмент фестончатого венчика (рис. 8), где глазурь по краям более толстая (хотя они обжигались венчиком вверх), что характерно для китайских изделий [Обухов, Волков 2007: 21]. На внешней стороне под венчиком - отпечатки эмалевой «сельджукской цепи» с позолотой между линиями, ниже - листья с эмалевыми контурами (в отдельных местах виден голубой слой эмали под толстым слоем иризации) и позолотой внутри них. На внутренней стороне сохранились только следы накладной эмалевой росписи. По отпечаткам видно, что это была надпись хорошим почерком насх (دفرد......), заключенная в контурные линии - фестончатую одинарную сверху и двойную прямую снизу.

Маджарский фрагмент - безусловно, фарфоровый. Сочетание фарфора и арабской надписи вызывает вопрос: китайское ли это изделие, выполненное с учетом персидских вкусов, или искусная персидская подделка фарфора с использованием надглазурной росписи в технике минаи?

Первый вариант ответа возможен. Во время династии Мин (1368-1644 гг.) в Китае широко распространились техники полихромной росписи: уцай (букв. 'пять цветов', что передает просто понятие многоцветности; без полутонов) и доуиай (букв. 'игра цветов', сочетание подглазурной и надглазурной росписи с полутонами). Это напоминает полихромные росписи в Иране и соседних странах (в самом общем смысле). Тогда рассматриваемый фрагмент может быть одним из первых опытов китайских мастеров в копировании на собственной продукции декора мусульманского мира.

Вторая версия представляется менее вероятной, хотя почти всё развитие художественной керамики позднего средневековья и Нового времени на Западе и Ближнем Востоке можно расценивать как подражание китайским эталонам. Попытки такого копирования Бируни упоминает еще в IX в. [Ал-Бируни 1963: 212]. Есть сообщения исследователей, что подделки невозможно отличить от оригиналов [Арапова, Рапопорт 1969: 27], однако находки XIV в., скорее всего, свидетельствуют об обратном. 
Подражаний китайским изделиям в Золотой Орде и Персии - очень много. Копировали селадон и бело-синий фарфор, но все они настолько легко отличаются от китайских изделий по составу формовочной массы и глазури, что говорить об умелом копировании технологии не приходится.

Возможен и третий вариант решения проблемы. На готовое китайское изделие (болванку) персидские мастера нанесли роспись, применяя известные им технологии. Само по себе это не является чем-то невозможным. К X в. относится описание «пиратского» изготовления люстровой росписи с применением уже готовых глазурованных чаш [Тифлиси 1976: 128]. В более позднее время в Голландии и Европе в целом практиковалась роспись фарфоровых китайских изделий.

На наш взгляд, первый вариант объяснения представляется наиболее вероятным. Если это так, тогда перед нами едва ли не первый датированный образец использования полихромной надглазурной росписи на китайском фарфоре.

Византийская керамика (рис. 9). Легко выделяется группа 15 [Масловский 2006: 397-399], представленная на всех золотоордынских городищах вплоть до Среднего Поволжья. Одна чаша с формовочной массой из этой группы имеет форму поддона, наиболее характерную для другой, 14-й группы, но с нехарактерной обработкой поверхности - брызгами марганцевого красителя. Сама 14-я группа [Масловский 2006: 392-397] керамики византийского происхождения также представлена на Маджарском городище, причем есть экземпляр с нехарактерной для группы подглазурной росписью ангобом.

Иногда однозначное отнесение импорта к какой-либо группе затруднено. Например, дно чаши с монограммой «Михаил» по формовочной массе ближе всего к группе Юго-Восточного Крыма, но имеет незначительные особенности глазури и остальной поверхности, что допускает ее происхождение с более отдаленных территорий.

\section{Выводы}

Не все группы дальнего, и особенно ближнего импорта выделены и локализованы в настоящее время. По мере накопления материала непременно найдутся группы импорта, представленные на других памятни- ках степной части Золотой Орды, добавятся и «экзотические» импорты из Закавказья и Северного Кавказа.

Соотношение групп импортной керамики показывает, что наиболее интенсивной была связь Маджара со столицами Золотой Орды и городами Восточного Крыма. Значительно слабее отмечены контакты с Азаком, Хорезмом, Ширваном. Стабильно, но в меньших количествах, в слое находилась керамика из Средней Азии (южнее Хорезма), Персии, Средиземноморья и с Балкан. На городище собрана выразительная и непропорционально большая коллекция разнообразных керамических импортов из Китая. Следует также отметить, что при массовом местном производстве и разнообразии изразцов импорт кашинного архитектурного декора из Поволжья в Маджаре представлен более широко, чем, например, в Азаке.

Вся учтенная керамика из Маджара датируется в рамках XIV в. и наглядно демонстрирует обширные торговые связи средневекового города, однако не в полном объёме раскрывает их. Об этом свидетельствуют археологические раскопки в 2015-2017 гг. (на незначительных площадях), где практически не обнаружены керамические материалы из Китая, Испании, соседнего Азака, Ширвана и др. [Валиев 2016; Бочаров 2017; Бочаров 2018], которые широко представлены в подъемных сборах разных лет. Такой результат ставит перед исследователями новые вопросы, связанные как с датировкой застройки разных частей города Маджара, так и с атрибуцией керамического импорта.

Ясность в данном вопросе могут внести дальнейшие археологические раскопки в различных частях памятника, которые позволят уточнить планировку города и больше узнать о роли средневекового Маджара в международной торговле.

\section{Источники}

Бочаров 2017 - Бочаров С. Г. Отчёт об археологических раскопках в Буденновском районе, г. Буденновск, на памятнике федерального значения «Городище Маджары» (раскоп XII, шурф 2) в 2016 году. В 2-х т. // НФ МА РТ ИА АН РТ. Ф. 4. Оп. І. Т. І. Казань, 2017. 202 л.

Бочаров 2018 - Бочаров С. Г. Отчёт об археологических раскопках в Буденновском районе, г. Буденновск, на памятнике федерального 
значения «Городище Маджары» (раскоп XII, раскоп XIII,) в 2017 году. В 2-х т. // НФ МА РТ ИА АН РТ. Ф. 4. Оп. І. Т. І. Казань, 2018. 242 л.

Валиев 2016 - Валиев Р. Р. Отчёт об археологических раскопках в Буденновском районе, г. Буденновск, на памятнике федерального значения «Городище Маджары» (раскоп XI, шурф 1) в 2015 году // НФ МА РТ ИА АН РТ. Ф. 4. Оп. І. Казань, 2016. 68 л. 139 илл.

\section{Sources}

Bocharov S. G. [Report on 2016 Archeological Excavations: Budyonnvovsky District, Budenovsk City, Federal Monument 'Town of Majar' (site XII, pit 2)]. In 2 vols. At: Tatarstan Academy of Sciences, Khalikov Institute of Archaeology, Museum of Archaeology, Scientific Archive. Fond 4. Ser.1 Vol. 1. Kazan, 2017. 202 p. (In Russ.)

Bocharov S. G. [Report on 2017 Archeological Excavations: Budyonnvovsky District, Budenovsk City, Federal Monument 'Town of Majar' (site XII, pit XIII)]. In 2 vols. At: Tatarstan Academy of Sciences, Khalikov Institute of Archaeology, Museum of Archaeology, Scientific Archive. Fond 4. Ser. 1 Vol. 1. Kazan, 2018. 242 p. (In Russ.)

Valiev R. R. [Report on 2015 Archeological Excavations: Budyonnvovsky District, Budenovsk City, Federal Monument 'Town of Majar' (site XI, pit 1)]. At: Tatarstan Academy of Sciences, Khalikov Institute of Archaeology, Museum of Archaeology, Scientific Archive. Fond 4. Ser. 1. Kazan, 2016. 68 p. 139 pic. (In Russ.)

\section{Литература}

Ал-Бируни 1963 - Абу-р-Райхан Мухаммед ибн Ахмед Ал-Бируни. Собрание сведений для познания драгоценностей (минералогия) / пер. А. М. Беленицкого; ст. и примеч. А. М. Беленицкого и Г. Г. Леммлейна. М.: Изд-во АН СССР, 1963. $521 \mathrm{c.}$

Арапова, Рапопорт 1971 - Арапова T. Б., Раnопорт И. В. К истории культурных связей Ирана и Китая в XVI - начале XVIII в. (по материалам керамического производства) // Искусство и археология Ирана: Всесоюзная конференция (1969 г.): Доклады. М., 1971. C. 19-34.

Булатов 1969 - Булатов Н. М. Классификация поливной керамики золотоордынских городов Нижнего Поволжья и Северного Кавказа: автореф. дисс. ... канд. ист. наук. М: Издво Моск. ун-та, 1969. 14 с.
Веневцева 1997 - Веневцева Н. В. Средневековая глазурованная керамика Кипра из собрания Эрмитажа // Памятники старины: концепции, открытия, версии. Памяти Василия Дмитриевича Белецкого 1919-1997. Т. 1. СПб.; Псков, 1997. С. 133-140.

Волков 1992 - Волков И. В. Керамика Азова XIV-XVIII вв. (Классификация и датировка): автореф. дисс. ... канд. ист. наук. М., $1992.26 \mathrm{c}$.

Волков 2001 - Волков И. В. Ширванский керамический импорт в Золотоордынских городах // Средняя Азия. История. Археология. Культура: Мат-лы конф., посвящ. 50-летию научной деятельности Г. В. Шишкиной. М.: Государственный музей Востока, 2001. C. $45-50$.

Волков 2016 - Волков И. В. Керамика золотоордынского города Маджара // Археология евразийских степей. Вып. 23. Мат-лы Маджарского археологического форума. Пятигорск-Будённовск-2012 г. Казань, 2016. С. 139-222.

Гражданкина, Ртвеладзе 1971 - Гражданкина Н. С., Ртвеладзе Э. В. Влияние Хорезма на керамическое производство золотоордынского города Маджара // Советская археология. 1971. № 1. С. 127-139.

Дудко 1963 - Дудко О. А. Поливная золотоордынская керамика по материалам городища Маджар // Сборник докладов на VI и VII Всесоюзных археологических студенческих конференциях. М.: МГУ, 1963. С. 106118.

Евтюхова 1965 - Евтюхова Л. А. Керамика Кара-Корума // Древнемонгольские города. М.: Наука, 1965. С. 274-296.

Жущиховская 2002 - Жущиховская И. С. Традиционное гончарство Китая // Вестник Дальневосточного отделения РАН. 2002. № 1. С. 85-98.

Масловский 2006 - Масловский А. Н. Керамический комплекс Азака. Краткая характеристика // Историко-археологические исследования в Азове и на Нижнем Дону в 2004 г. Вып. 21. Азов: Азовский краеведческий музей, 2006. С. 308-473.

Обухов, Волков 2007 - Обухов Ю. Д., Волков И. В. Китайская керамика из Маджара // Поливная керамика Восточной Европы, Причерноморья и Средиземноморья в XXVIII вв.: тезисы II междунар. науч. конф. (г. Ялта, 19-23 ноября 2007 г.). Ялта: Крымский филиал ИА НАНУ, 2007. С. 20-25. 
Полубояринова 2003 - Полубояринова М. Д. Китайский селадон из Болгара // Российская археология. 2003. № 2. С. 155-164.

Тифлиси 1976 - Тифлиси, Абу-л-Фазл Хубайш. Описание ремесел (Байан ас-сана-ат) / пер., введ. и коммент. Г. П. Михалевич. М.: Наука, 1976. $256 \mathrm{c}$.

Фёдоров-Давыдов 1994 - Фёдоров-Давыдов Г. А. Золотоордынские города Поволжья. М.: Изд-во МГУ, 1994. 228 с.

Vandiver P., Kingery W. The technology of celadon glazes. Ceramics Monthly. 1987. Vol. 35, No. 7. Pp. 55-56. (In Russ.)

\section{References}

Abū Rayḥān Muḥammad ibn Aḥmad Al-Bīrūnī. [Gems - Geology Manual of Minerals and Gems]. A. Belenitsky (transl., comm.), G. Lemmlein (comm.). Moscow: USSR Academy of Sciences, 1963. 521 p. (In Russ.)

Arapova T. B., Rapoport I. V. Revisiting cultural ties between Iran and China: $16^{\text {th }}-$ early $18^{\text {th }}$ centuries (a case study of ceramics manufacture). In: [Arts and Archaeology of Iran]. Conf. proc. (1969). Moscow, 1971. Pp. 19-34. (In Russ.)

Bulatov N. M. [Classification of Glazed Ceramics from Golden Horde Cities of the Lower Volga Region and North Caucasus]. A Cand. Sc. (history) thesis abstract. Moscow: Moscow State University, 1969. 14 p. (In Russ.)

Dudko O. A. Glazed ceramics of the Golden Horde: a case study of materials from the town of Majar. In: $\left[6^{\text {th }}\right.$ and $7^{\text {th }}$ All-Union Student Conferences: Collected Reports]. Moscow: Moscow State University, 1963. Pp. 106-118. (In Russ.)

Evtyukhova L. A. Ceramics of Karakorum. In: [Ancient Mongolian Cities]. Moscow: Nauka, 1965. Pp. 274-296. (In Russ.)

Fedorov-Davydov G. A. [Golden Horde Cities of the Lower Volga Region]. Moscow: Moscow State University, 1994. 228 p. (In Russ.)

Grazhdankina N. S., Rtveladze E. V. Influence of Khwarazm on ceramics manufacture in the Golden Horde town of Majar. Sovetskaya arkheologiya. 1971. No. 1. Pp. 127-139. (In Russ.)
Maslovsky A. N. Ceramics of Azaq: brief characteristics. In: [Historical and Archaeological Investigations in the Azov and Lower Don Regions: 2004]. Vol. 21. Azov: Azov Local Lore and History Museum, 2006. Pp. 308-473. (In Russ.)

Obukhov Yu. D., Volkov I. V. Chinese ceramics from Majar. In: [Glazed Ceramics of Eastern Europe, the Black Sea and Mediterranean: $10^{\text {th }}$ $-18^{\text {th }}$ Centuries]. Conf. proc. (Yalta; November 19-23, 2007). Yalta: Crimean Branch of Institute of Archaeology, NANU, 2007. Pp. 2025. (In Russ.)

Poluboyarinova M. D. Chinese celadon from Bolgar. Rossiyskaya arkheologiya. 2003. No. 2. Pp. 155-164. (In Russ.)

Tiflisi Abu-1-Fazl Khubaish. [Description of Crafts (Bayan as-sana-at)]. G. Mikhalevich (transl., etc.). Moscow: Nauka, 1976. 256 p. (In Russ.)

Vandiver P., Kingery W. The technology of celadon glazes. Ceramics Monthly. 1987. Vol. 35, No. 7. Pp. 55-56. (In Russ.)

Venevtseva N. V. Cyprus-manufactured medieval glazed ceramics housed by the State Hermitage Museum. In: [Monuments of Antiquity: Concepts, Discoveries, Versions. Commemorating Prof. V. D. Beletsky (1919-1997)]. Vol. 1. St. Petersburg; Pskov, 1997. Pp. 133140. (In Russ.)

Volkov I. V. [Ceramics of Azov: $14^{\text {th }}-18^{\text {th }}$ Centuries]. A Cand.Sc. (history) thesis abstract. Moscow, 1992. 26 p. (In Russ.)

Volkov I. V. Imported Shirvan ceramics in Golden Horde cities. In: [Middle Asia: History, Archaeology, Culture]. Conf. proc. Moscow: State Museum of Oriental Art, 2001. Pp. 45-50. (In Russ.)

Volkov I. V. The Golden Horde town of Majar: ceramics. In: [Archaeology of the Eurasian Steppes]. Vol. 23. Proc. of the Archaeological Forum 'Pyatigorsk-Budennovsk-2012'. Kazan, 2016. Pp. 139-222. (In Russ.)

Zhushchikhovskaya I. S. The traditional pottery of China. Vestnik of the far East Branch of the Russian Academy of Sciences. 2002. No. 1. Pp. 85-98. (In Russ.) 

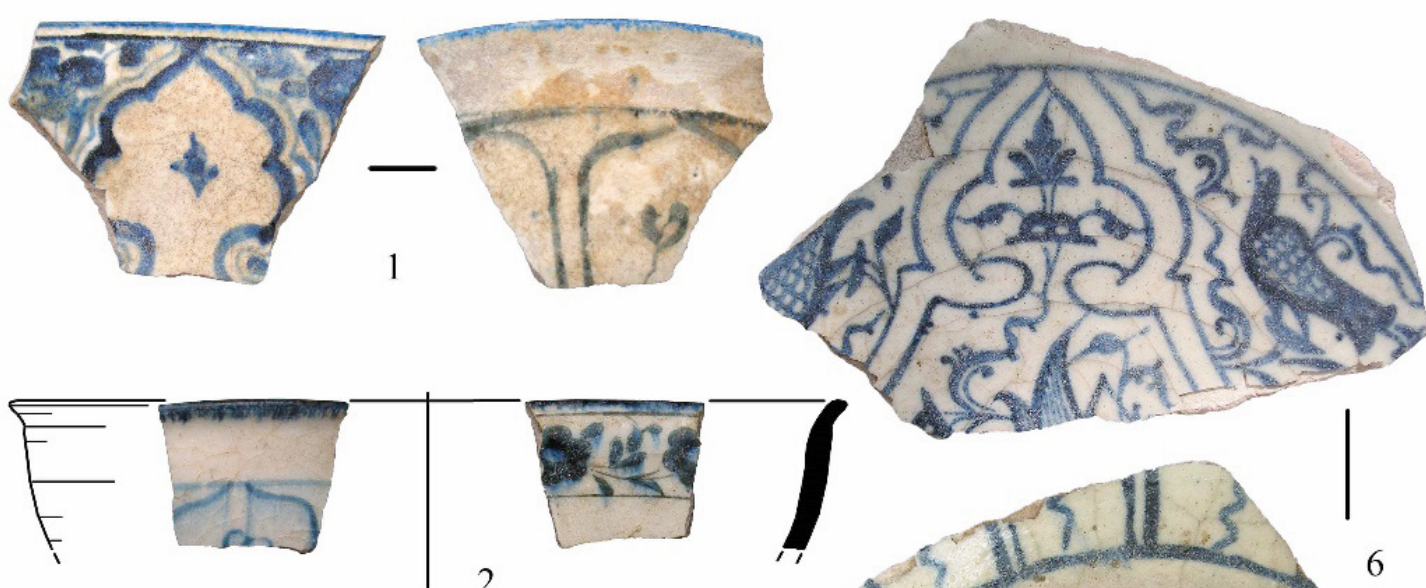

2
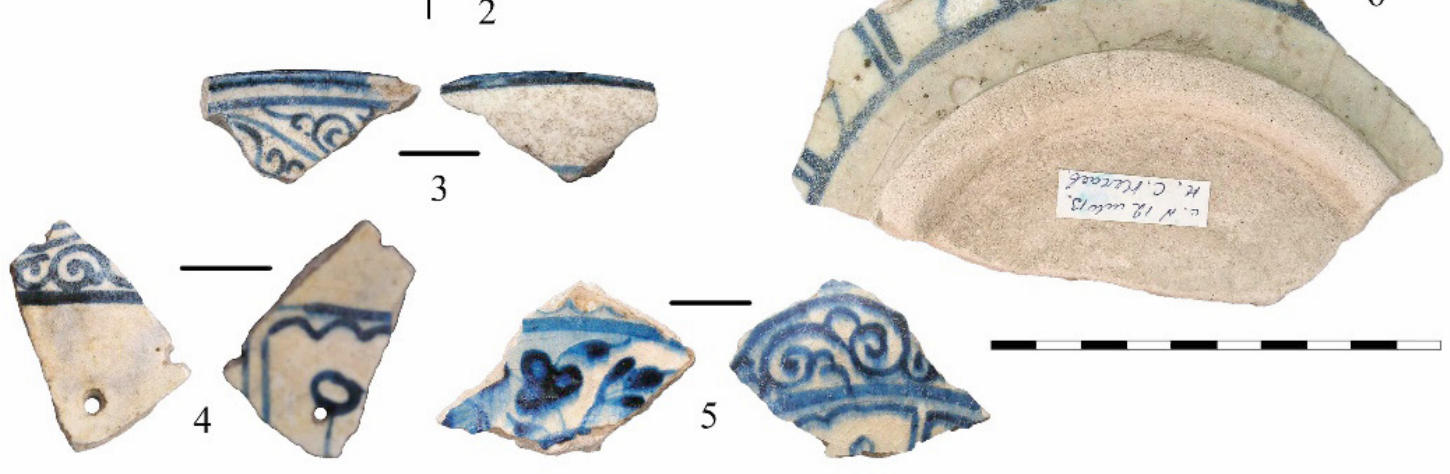

6

Рис. 1. «Тимуридская» керамика с подглазурной росписью кобальтом. 2 - для контурной росписи дополнительно использован черный цвет. Приобретения Ю. Д. Обухова

[Fig. 1. Timurid ceramics decorated in underglaze cobalt blue. 2 - contour lines painted in black. Collected by Yu. Obukhov.] 

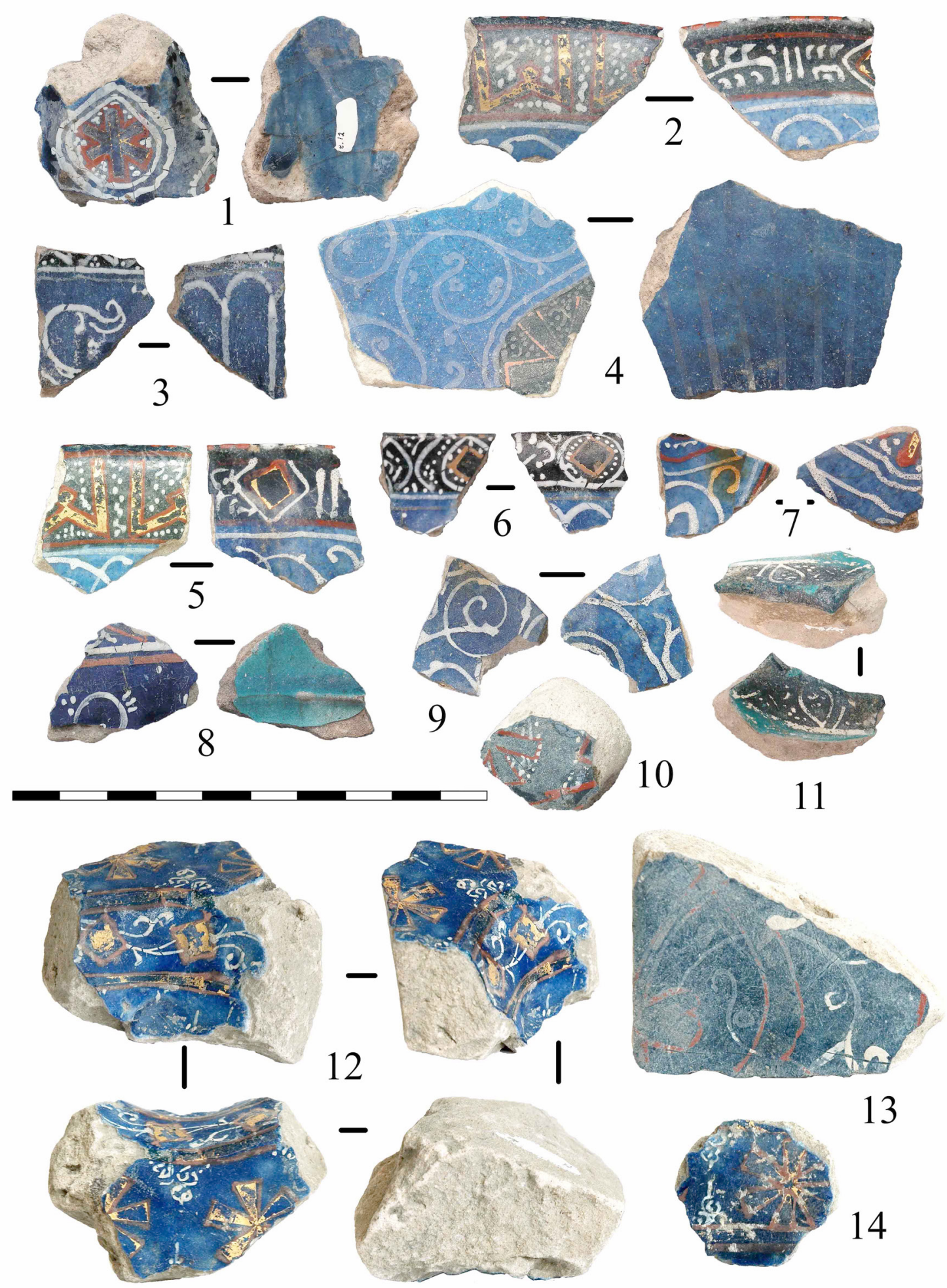

13

Рис. 2. Ладжвардина - кашинная керамика с глухой, полупрозрачной или прозрачной глазурью, окрашенной кобальтом, и надглазурной росписью эмалями с наложением золотой фольги. 8 - фрагменты закрытых сосудов; 2-9, 11, 14 - фрагменты чаш; 12-13 - архитектурный декор; 10 - архитектурный декор с вторичной обработкой.

[Fig. 2. Lajvardina - kashi ceramics with opaque, scumble or translucent glaze decorated in cobalt and overglaze enamel painting with gold foil covering. 8 - fragments of closed vessels; 2-9, 11, 14 fragments of bowls; $12-13-$ architectural decoration; $10-$ architectural decoration with secondary finishing.] 

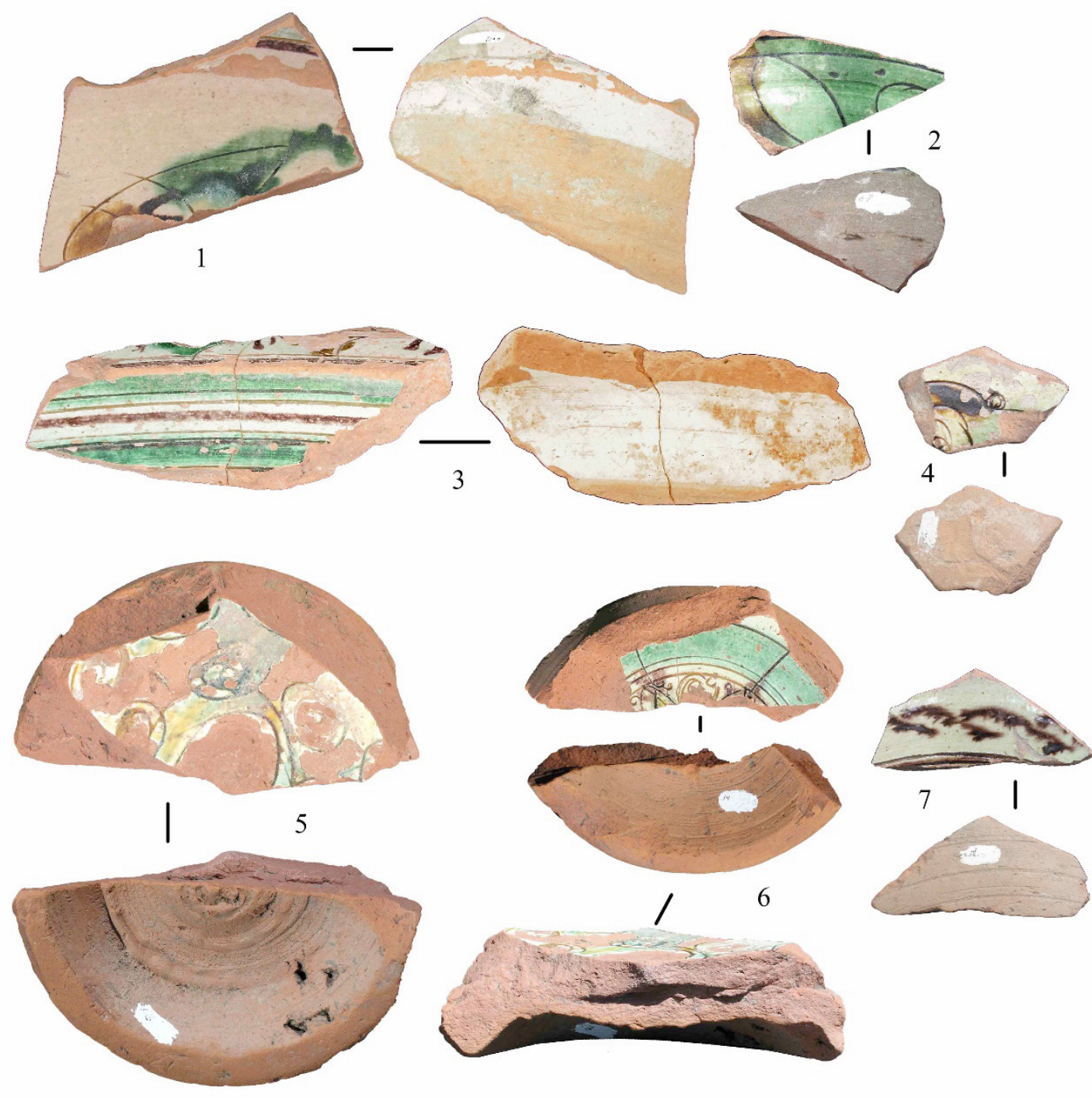

Рис. 3. Фрагменты блюд группы Ширвана. Сборы Ю. Д. Обухова

[Fig. 3. Fragments of plates. Shirvan ceramics. Collected by Yu. Obukhov.] 

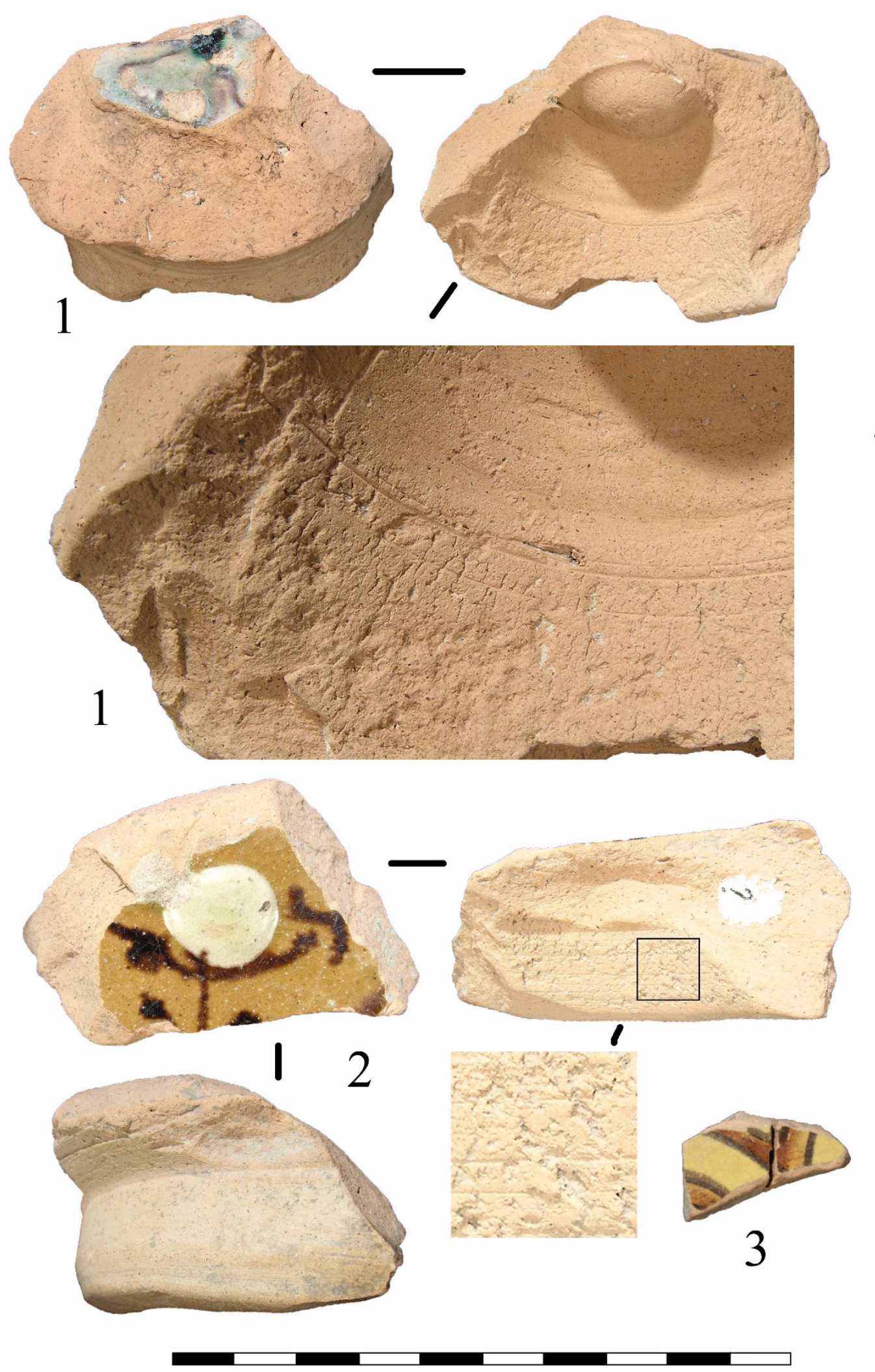

Рис. 4. Фрагменты керамики из бассейна Сырдарьи или сопредельных регионов. Видны вырезные поддоны, характерные трещинки от гончарного ножа. Сборы Ю. Д. Обухова.

[Fig. 4. Fragments of ceramics from the Syr Darya River Valley and adjacent areas. Collected by Yu. Obukhov.] 

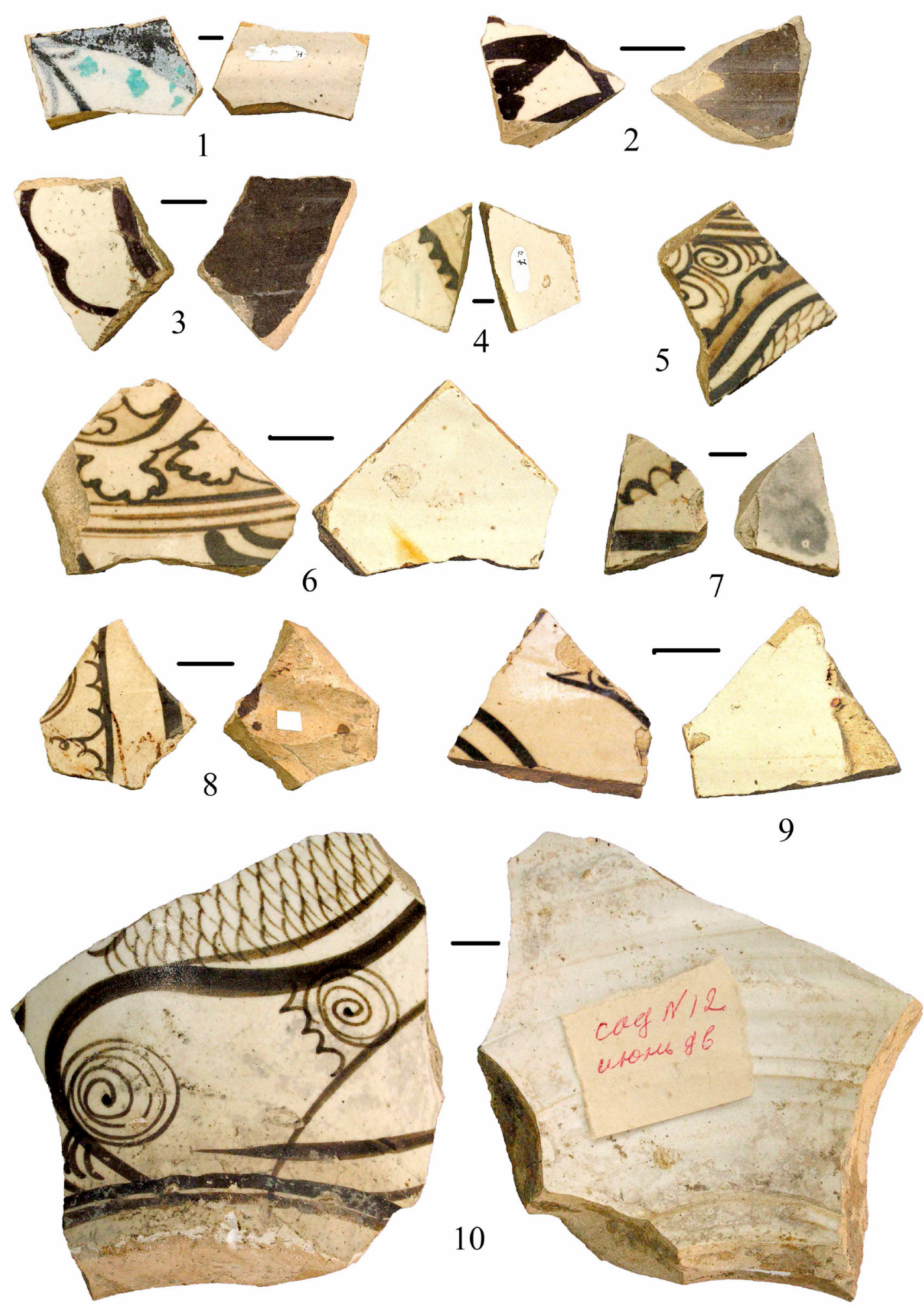

Рuc. 5. Китайская керамика цычжоу с коричневой и желтоватой росписью по светлой глазури. $1-$ с остатками бирюзовой глазури поверх основной кроющей. 1-10 - фрагменты стенок сосудов. Приобретения Ю. Д. Обухова.

[Fig. 5. Cizhou ceramics (China) painted in brown and yellow over pale glaze. 1 - visible are remains of turquoise-colored glaze over the opaque one. 1-10 — fragments of vessel walls. Collected by Yu. Obukhov.] 

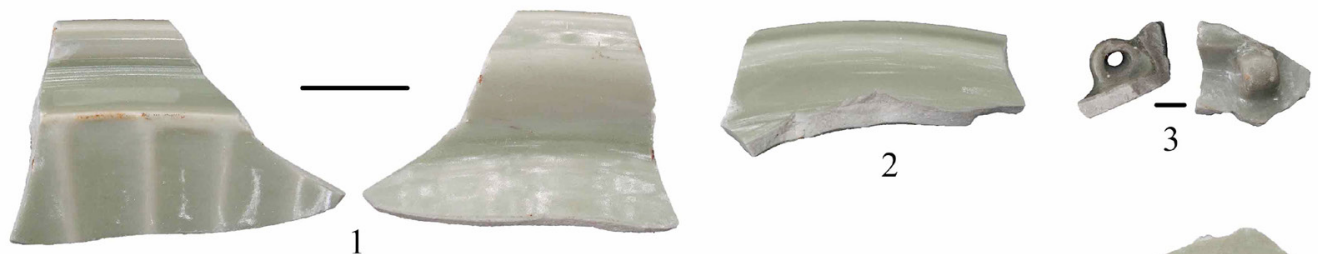

1

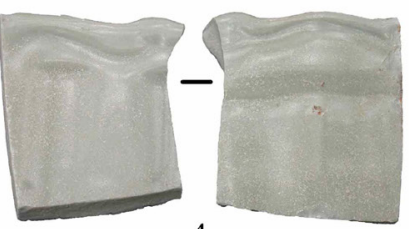

4

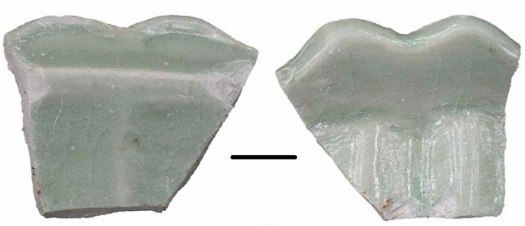

5

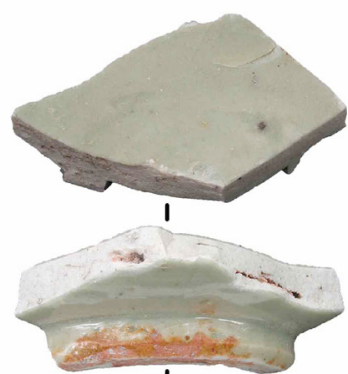

6
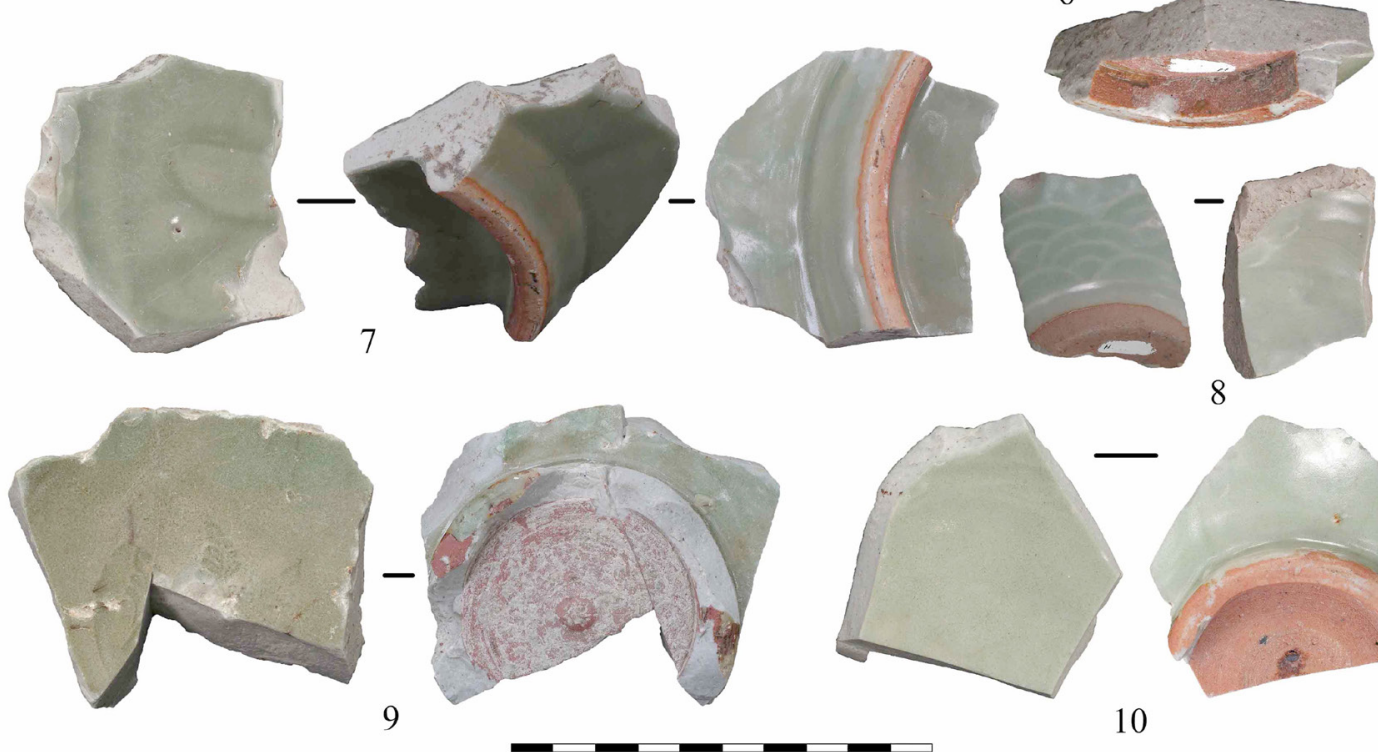

10

Рис. 6. Селадон. Приобретения и сборы Ю. Д. Обухова.

[Fig. 6. Celadon. Collected by Yu. Obukhov.] 

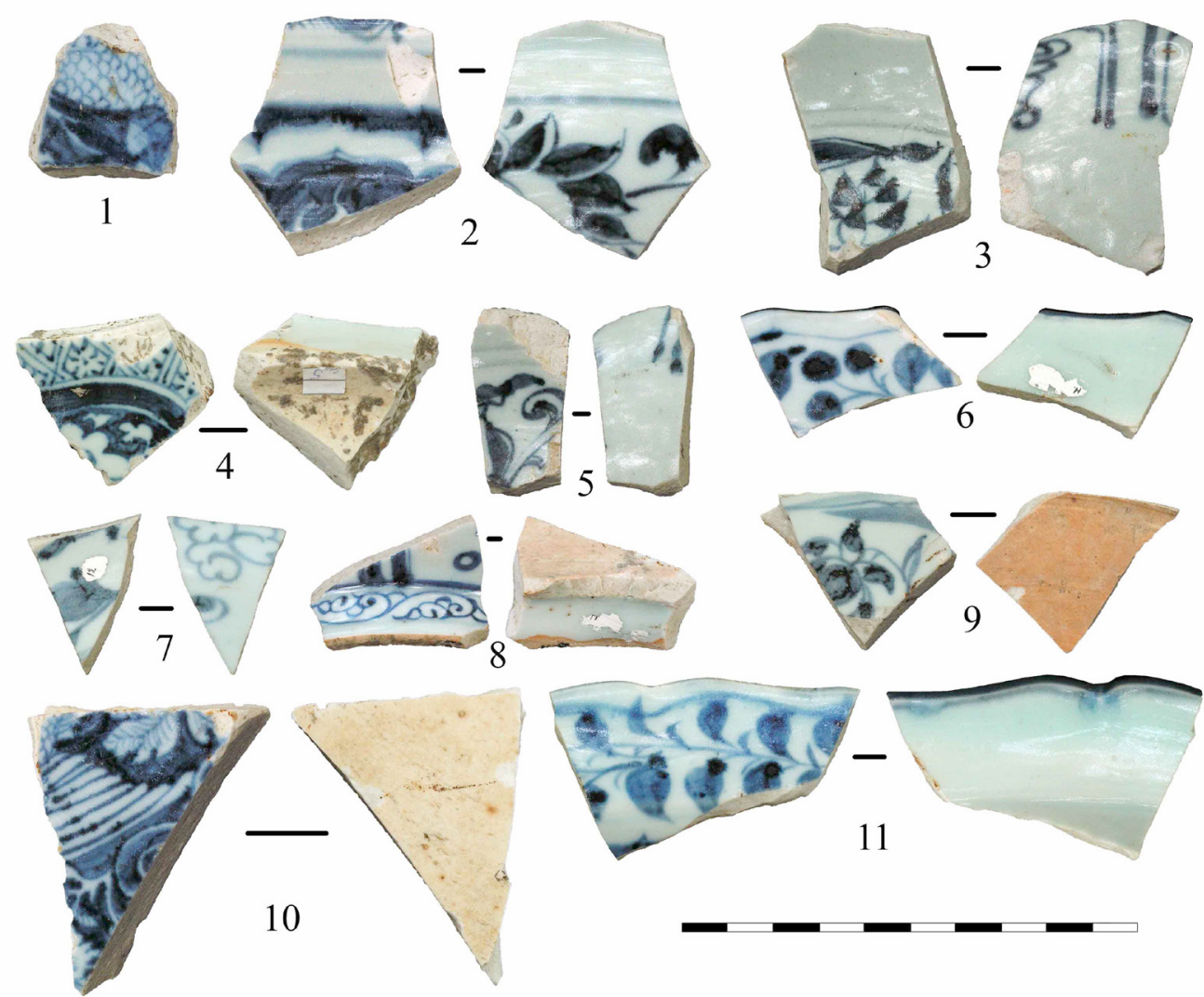

\section{9}

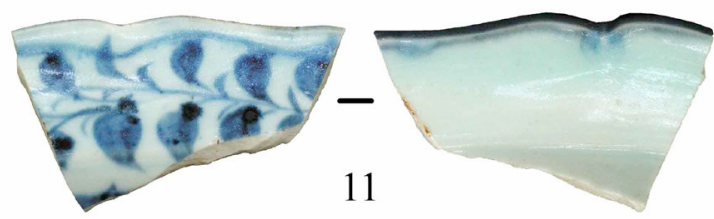

Рuc. 7. Китайский фарфор с одноцветной кобальтовой росписью («цинхуа»). Сборы Ю. Д. Обухова

[Fig. 7. Chinese porcelain painted in cobalt (Qinghua). Collected by Yu. Obukhov.]
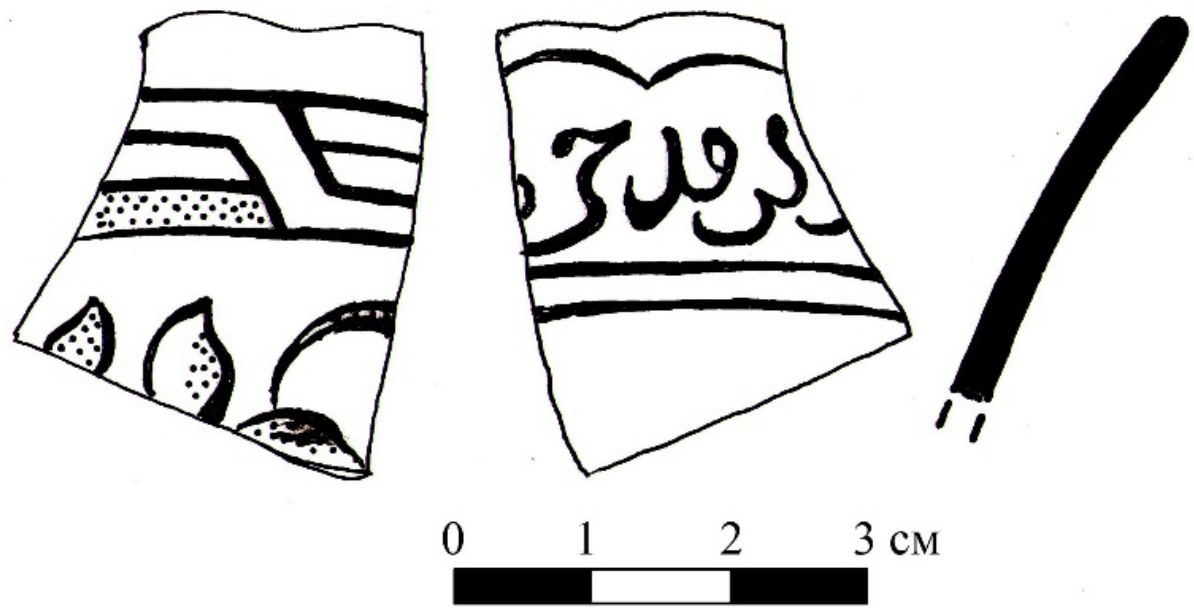

Рис. 8. Фрагмент фарфоровой чаши с надглазурной росписью. Сборы Ю. Д. Обухова [Fig. 8. Fragment of a porcelain bowl with overglaze painting. Collected by Yu. Obukhov] 

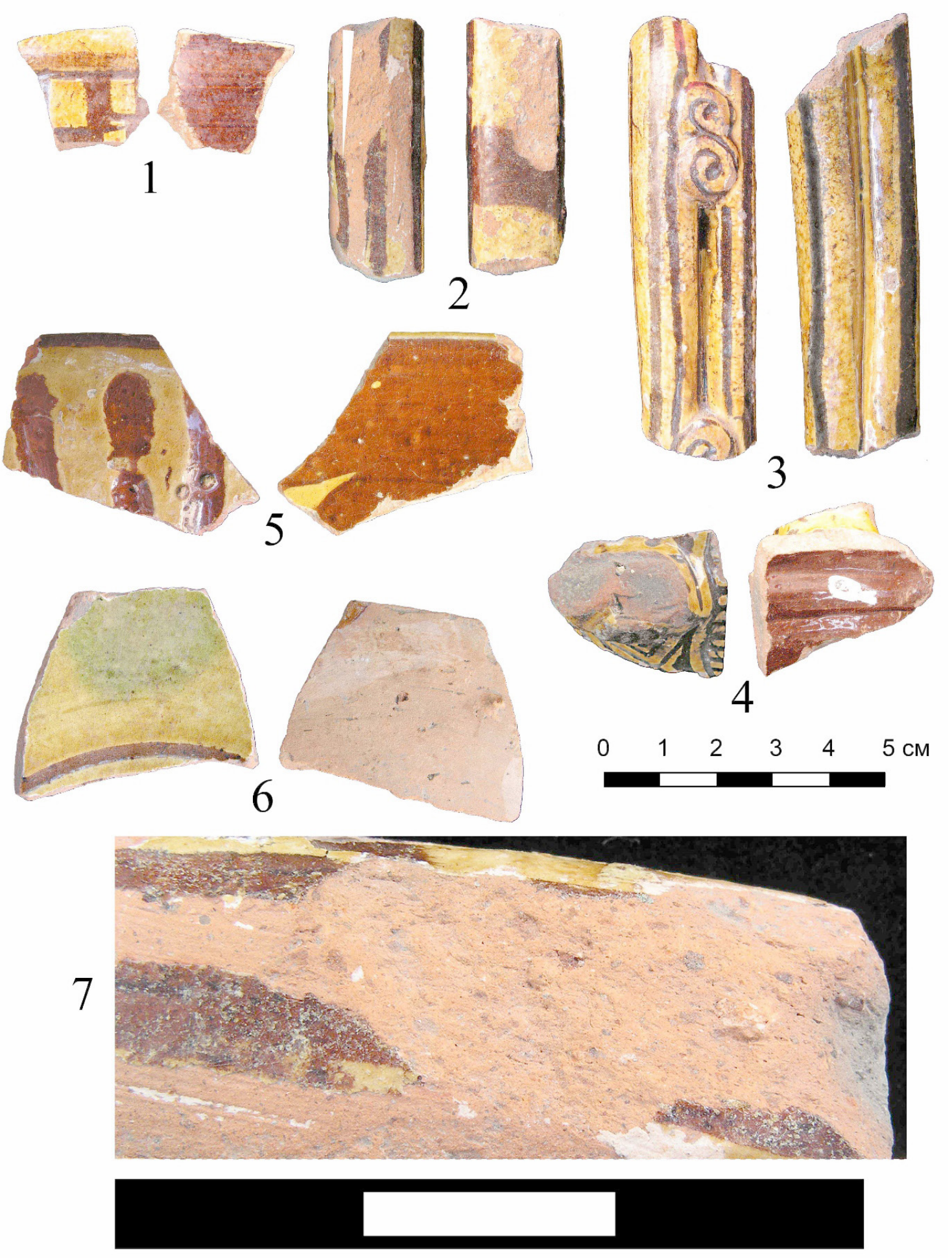

Рис. 9. Византийская керамика, группа 15. Сборы Ю. Д. Обухова.

[Fig. 9. Byzantine ceramics. Group 15. Collected by Yu. Obukhov] 